\title{
The 21st Century Maritime Silk Road And China's Engagement With Asean : Is It China's Shift Fromuse Of Hard Power To Strategic Smart Power With Chinese Characteristics?
}

\author{
Ephraim Abele Kayembe \\ - PhD Student in International Relations at Central China Normal University's School of Politics \\ and International Studies, Wuhan City, Hubei Province, People's Republic of China
}

\begin{abstract}
One of emerging central claims in the field of International Cooperation as regards to Chinese engagement with ASEAN countries is that China has conceptualized and developed the $21^{\text {st }}$ Century Maritime Silk Road (NMSR) as a strategy of strategic shift from the total use of hard power tools to deployment of a combination of both hard and soft power tools as new mechanisms of engagement with ASEAN with the aim of consolidating Chinese influence over ASEAN so as to reduce serious tensions over territorial disputes in South China Sea.Drawing on the significance of the $21^{\text {st }}$ Century Maritime Silk Road and the theoretical perspectives of hard power and soft power, this paper argues that there is a realization on the part of China that it is for its own strategic benefit not only to rely on the use of hard power strategies as mechanisms of engagement with ASEAN, but rather move towards a combined use of hard and soft power tools if it were to gradually reduce tensions over territorial disputes in South China Sea. This combined use of hard and soft power mechanisms in its engagement with ASEAN through the NMSR is what the researcher regards asStrategic Smart Power with Chinese Characteristics.

The logic of Strategic Smart Power with Chinese Characteristics is that the aspect of soft power strategies in it could be utilized by Chinato attract ASEAN countries into its economic and political zone of influence so as to peacefully persuade and attract ASEAN to reduce tensions and solve territorial sea disputes through bilateral approaches. The hard power strategies in the strategic smart power as defined in terms of economic benefits are used as carrots for ASEAN to engage more with China than the U.S, while the developing Chinese Military orientation in the Sea is deployed as counter-balance to the U.S's strategic military alliance andthe buildup of military arsenal in South China Sea. Through the $21^{\text {st }}$ Century MSR, the paper argues that China is shifting from the full use of hard power tools of engagement with ASEAN to usage of strategic smart power for purposes of advancing its own political and economic agenda in line with the geopolitics of South China Sea. Through the analysis in this paper, the researcher has critically explored and evaluated the issue of distinguishing clear signs of Chinese hard power and soft power in its engagement with ASEAN countries in South China Sea through the joint implementation of the NMSR. The paper has therefore argued that use of smart power by China as a strategic of deepening its economic and political engagement with ASEAN through NMSR is only a self-serving mechanism aimed at achieving its own geopolitical interests in South China Sea. The dichotomy that is there between use of hard and soft power is in its totality a contradiction to Chinese dream of establishing a peaceful environment in the South East Asia for economic development and prosperity. Notwithstanding the need to use NMSR as a strategy for resolving long term territorial disputes in SCS, the researcher argues that that the conception of shift from deployment of hard power to strategic smart powerwill not be an easy matter for China, since within the calculus of its engagement with ASEAN countries, the U.S brings into the equation an aspect of hard power to protect its own geopolitical and security interests. It is this U.S's deployment of hard power mechanisms that has motivated China to develop its strategic smart power through NMSR as a new strategy of engagement with ASEAN in anticipation that the soft power aspect could gradually suffocate U.S's influence over ASEAN while the hard power aspectscould counter-balance the U.S military alliance and buildup of military arsenal.
\end{abstract}

Key Words:- $21^{\text {st }}$ Century New Maritime Silk Road, Hard and Soft Power, Strategic Smart Power, Territorial Disputes and Joint Economic Development and Prosperity

\section{INTRODUCTION}

Ever since President XiJinxing came to power to replace Hu Jintao after the expiry of his term in office, some strategic decisions have been undertaken in terms of Chinese engagement with the outside world. One of the critical decisions that he has undertaken and eventually attracted much global attention is his idea of 
the $21^{\text {st }}$ Century Maritime Silk Road (MSR) as conceptualized within the development framework of One Belt, One Road. The genesis of the development thoughts of MSR is linked to President Xi Jinxing's speech which he delivered at Nazargayey University in Kazakhstan in September 2013 when he emphatically suggested that there was need for the international community to address issues of emerging global sluggish economies especially in Asia by developing and forging closer economic ties, deepen cooperation and provide solutions to issues challenging regional integration, economic interdependence, infrastructure development and establishment of free trade areas especially in Asia [1] . During the delivery of the speech, he suggested and advanced an idea that China would push ahead to spearhead the construction of New Silk Road and Economic Belt so as to link China with Europe, Africa and Central Asia and Middle East through the land based and Maritime based infrastructures.This particular speech was followed up by another speech he delivered at the Indonesian Parliament in October 2013 when he touched on the need for China and ASEAN to construct the $21^{\text {st }}$ Century Maritime Silk Road so that it could provide opportunities to interconnect the economies, deepen cooperation, unblock challenges to regional trade and address the problem of contraction of global trade. This speech that President Xi Jinping made in Indonesia was an excellent carbon copy of the issues that Premier Li Keqiang also previously highlighted at the $16^{\text {th }}$ China-ASEAN summit in Brunei in 2013 [2].All these speeches continue attracting the attention of the International Community more especially because China being an emerging global economic power house is seen as a challenger to the U.S hegemony. What has attracted more attention to these speeches was that the International Community want to understand what type of development policies and power could be displayed by China as an a perceived automatic global challenger to the U.S hegemony as it evolved from the leadership of Hu Jintao to the new leadership of President Xi Jinping. Every nation-state especially the great powers and ASEAN countries were interested in knowing and deciphering the meaning of any development thought that could be pursued by President Xi and what that meant in terms of China's engagement with outside world as it pursues such development framework whether at domestic or international level.Bearing in mind that the development initiative of NMSR was announced by the new leadership of Xi Jinping, an interest has developed to understand whether China is bringing new mechanisms of engagement with the outside world. To this effect, understanding the emerging Chinese mechanisms of engagement with ASEAN in South China Sea through the NMSR became and is still an issue of global interest. The Outside world wants to understand whether through the $21^{\text {st }}$ Century MSR, China is now shifting from deployment of full hard power to usingstrategic smart power with Chinese characteristics as new mechanism of engagement with ASEAN in South China Sea Region. Most scholars also want to understand whether this perceived shift from use of hard power to strategic smart power by China is a new tactic of influencing or persuading ASEAN to reduce tensions and solve issues of territorial disputes bilaterally through the help of soft power mechanism imbedded inMSR while it simultaneously using the hard power aspect as carrots for ASEAN [3] and the developing military hard power as counter-balance to the U.S security factor in the calculus of its engagement with ASEAN.They also want to understand whether the shift will be a complicated task for China considering the fact that issues of territorial disputes in South China Sea are so complicated that other new players including the USA have got alsogeostrategic interests as well in the same SCS region. The geopolitical and securityinterests of the USA necessitate it to try and bring along the aspect of hard power into the calculus of Chinese engagement with ASEAN. In this paper, the researcher argues that in trying to counter-balance the USA hard power, China will at times reciprocate with deployment of military hard power while at the same time will use its economic hard power and soft power emanating from the NMSR to persuade ASEAN countries achieve its preferred outcomes in the economic, political and security field.But bearing in mind that ASEAN is an integral part of China's economic growth and development [4], I argue that China will not fully use hard power mechanisms against ASEAN countries, but rather deploy a mix of soft and hard power so as to strike a proper balance on its national economic and security interests in South China Sea. The combination of soft and hard power deployment will be called Strategic Smart Power with Chinese Characteristics.

In trying to execute the task of this paper as outlined herein, I will be guided by the following research question:

Is Chinese engagement with ASEAN Countries through the $21^{\text {st }}$ Century MSR a clear indication of its shift from full use of hard power to strategic smart power with Chinese Characteristics?

In addressing this question, I will first explain the theoretical concepts of hard and soft power and indicate how and under what circumstancesthese are generally used as mechanisms of engagement between nation-states. After explaining this, I will zero-in on traditional methods of Chinese engagement with ASEAN and indicate why currently there appears to be a shift from solely using hard power mechanism to the use of strategic smart power with Chinese characteristics. I will then explain what strategic smart power with Chinese characteristics entails. After doing this, I will fully discuss the development framework of NMSR and strive to isolate clear elements of both hard power and soft power in the Chinese engagement with ASEAN.

The researcher will then conclude the paper by highlighting that Chinese use of Strategic Smart Power is motivated by the USA orientation towards bringing in aspects of hard power into the calculus of Chinese 
engagement with ASEAN countries in South China Sea. Of course it will category be emphasized that the NMSR could be an opportunity for China to consider striking a proper balance in using both hard power and soft power to achieve its preferred outcomes in political and security arenas based on the dictates of geopolitics of NMSR in South China Sea.

\section{THE THEORETICAL CONCEPTS OF HARD AND SOFT POWER}

In international relations, much discussion on issues of power is focused on how a country strikes a balance between use of hard power and soft power strategies when engaging with other countries. The attention on these two types of power increases significantly when the country being considered is either an established power or an emerging power. The emerging power is generally perceived as an automatic challenger to the established hegemony even if it may not have such intentions [5].In this paper, we are trying to evaluate whether China's engagement with ASEAN countries through the NMSR in South China Sea has got clear signs of Chinese shift from full use of hard power to strategic smart power. The paper also wants to explore whether we could distinguish clear elements of both hard power and soft power in the engagement. It will further evaluate the motivation behind using both types of power simultaneously considering that the U.S has got also strategic geopolitical and security interests in the implementation of MSR in South China Sea. We will further explore whether the implementation of MSR could be an opportunity for China to reduce tensions and solve territorial disputes in South China Sea. In order to execute this task, we will now explain the three concepts of hard power, soft power and strategic smart power with Chinese characteristics and apply these to isolate critical elements of both hard and soft power in the MSR.

\subsection{Theoretical Perspectives of Hard Power, Soft Power and Strategic Smart Power engagement strategies between countries in the International System}

The issue of strategic smart power is becoming very popular in the Chinese Government power echelon as it pursues the implementation of its development framework of NMSR[6]. This is basically because China has realized that the total use of hard power is proving to be problematic for it to achieve its intended and preferred outcomes in establishing and extending its influence over ASEAN countries so that they could do what it wants them to do. The shift from hard power to strategic smart power is therefore an alternative mechanism of achieving the same desired outcomes but by striking a proper balance between use of coercion or induced payment with attraction strategies. The concept of smart power is based on the logic of combining hard power and soft power [7]. The strategic smart power with Chinese characteristics will be explained within the context of these two aspects as applied by China in its engagement with ASEAN countries through MSR. It is therefore important to discuss soft power and hard power first, for us to explain better the concept of strategic smart power with Chinese characteristics.

By definition, soft power is considered by many scholars as the national capability to attract other countries do what a nation-state wants them to do without coercing them. For example, some scholars have defined soft power as the ability to get what you want through attraction rather than coercion or payment. He indicated that a country develops its soft power through culture, values and foreign policies it pursues when engaging with the outside world [8]. In his reasoning, scholar [8] thinks that countries can either be attracted to you through the nature of your foreign policies you are pursuing if they are seen to be non-coercive and friendly to one's national interest or when your culture and values advances the general interests and aspirations of other countries. The logic of this explanation demands that countries should master the statecraft of developing foreign policies that are more appealing to others if they were to get what they want through attraction to achieve intended and preferred outcomes on foreign engagement.

This definition of soft power is also quite similar to the thinking of other scholars who in their considered views separately defined soft power in terms of the capability of getting others to do something they would not otherwise do $[9,10]$. These scholars emphasized the need to affect others through co-optive means of framing the development agenda, persuading and eliciting positive attraction in order to obtain preferred outcomes. Some scholar [11] extended his thoughts on soft power when he included elements of understanding the interests of other nations so that the crafting and implementation of foreign policies are not in conflict with the national interests of the target states which a state desires that they be attracted to it. This is very important as it signifies how desired outcomes within the foreign policy of a nation- state are going to be effectively achieved. What matters most in the soft power strategy of engagement is the use of national resources that can lead to a country's ability to affect others through co-optive means. Questions are raised on what kind of policies are being promoted, can countries get attracted to such policies and what kind of communication mechanisms are deployed to explain the intention of those development policies being pursued.

Although the preceding scholars have indicated that countries could be attracted to other states through their culture, values and policies; some scholar has highly criticized such reasoning as he felt attention and attraction follows the concentrations of capabilities and resources such that no country could afford losing such 
opportunities [12]. Scholar [12] reasoned that other actors in the international system are able to attract others only when they have the ability and resources to do so, otherwise no country would be attracted to them. But regardless of this, it should be noted that countries sometimes can opt not to associate with particular countries based on foreignpolicy agendas they are pursuing [13]. This is a very important aspect when examining the soft power strategies that could be designed to attract others.From this discussion so far, it is clear that soft power rests heavily on the ability to set political agenda in a way that shapes the preferences of others. A political agenda that positively affects other countries' preferences are imbedded in the foreign policies which countries try to emulate or get attracted to. Because policies have to be implemented, the development of institutions that could implement those policies becomes paramount. In case of our study, we will explore whether we could isolate soft power strategies out of the NMSR Initiative and see how those strategies are reinforcing the desire to reduce tensions and solve territorial disputes in South China Sea.

Unlike soft power, hard power has been defined by various scholars as the use of military or economic coercion to get others change their position in preference to what outcomes you want $[14,15,16]$. The economic coercion as a strategy of advancing hard power engagement mechanisms are based on using the inducement of economic aid, withholding development aid or pushing for economic sanctions as tools of achieving compliance on doing something. This inducement is generally referred to as carrots in the field of International Politics [17, 18]. The military aspect within the hard power mechanism of state engagement is based on the use of threats (sticks) in form of military hardware buildup as a strategic threat or deterrence for states to do or not to do something.

Because the use of either hard power or soft power alone is not effective enough within the context of the dynamic political and security environment of international realism, states prefer to use a combination of these so that they could be unleashed when circumstances demand their use. China through NMSR increasingly appear to be following the logic of using strategic smart power with Chinese characteristics to achieve its preferred outcomes in areas of political, economic and security sectors in the South China Sea. For purposes of this paper, strategic smart power with Chinese characteristics is defined in terms of using soft power mechanisms to attract ASEAN countries do what China wants while deployment of hard in form of economic and financial benefits is to give carrots to ASEAN to engage more with China. The developing military buildup in South China Sea is to deter and counter-balance the military threat coming from the existing U.S military alliance and arsenal builds up in the sea region [19].

Having explained these three concepts, the researcher will now turn attention to discussing fully the concept of NMSR initiative and attempt to isolate both elements of hard power and soft power mechanism of engagement between China and ASEAN.

\section{CHINA-ASEAN ENGAGEMENT THROUGH THE $21^{\text {ST }}$ CENTURY MARITIME SILK ROAD}

The $21^{\text {st }}$ Century MSR is the development thought of President Xi Jinping which was announced before Parliament of Indonesia on $3^{\text {rd }}$ October, 2013 with the main aim of promoting and deepening regional economic integration and cooperation, forging economic ties, opening up maritime-based trade corridors, developing seaports infrastructure, advancing coordinated economic production and improving connectivity along the MSR [20].

Through the establishment of Asian Investment Infrastructure Bank (AIIB) based on the logic of One Belt One Road, the Bank will offer economic opportunities to ASEAN countries implement seaport and other infrastructure projects under the NMSR [21]. It will improve trade and promote people to people exchange. One of the critical areas where this initiative will be implemented is in the South China Sea where it presents opportunities for ASEAN countries to engage more with China regardless of the geopolitical nature of the environment in the sea.

As important as it is, the NMSR has raised quite a number of questions and concerns on the part of both ASEAN and other geopolitical players in the South China Sea. While it is recognized that the $21^{\text {st }}$ Century NMSR could strengthen and solidify the regional trade and continued economic cooperation and interdependence between China and ASEAN countries [21], both ASEAN and the U.S are still questioning the real intention of the initiative based on the geopolitical dimensions of the development framework. Some are questioning whether this is a Chinese way of displaying economic prowess and perceived new status of emerging challenger to the current U.S hegemony to the world. Others are concerned that maybe china could use it as a strategy to dominate and re-draw the world economic and security order through the initiatives instead of continuing with its development philosophy of peaceful development [23]. While Some scholars believe that through this initiative China can choose to be a responsible great power or challenger to the U.S existing hegemony [24], other scholars have emphasized that this is just a strategy of counter-balancing the U.S Asia-Pacific Pivot and Rebalancing Strategy [25].In relation to the NMSR being described as a an opportunity for ASEAN to access economic and financial benefits, this paper will evaluate what elements of hard power and 
soft power could be distinguished out of the implementation of this development initiative. On the claim that the NMSR is a response to the U.S's Asia-Pacific pivot, this paper will attempt to evaluate whether the deployment of hard power and soft power strategies by China is for purposes of developing and exercising its economic, security and political influence over ASEAN and other players in the South China Sea Region. To this effect, it becomes necessary to explore and understand whether we could isolate both hard power and soft power mechanisms within the strategic smart power of China being exercised through the NMSR.

\subsection{Hard Power Elements in the $21^{\text {st }}$ Century Maritime Silk Road}

Recalling that hard power was defined as the ability to use military or economic coercion to get others to change their position on certain policies [11] and further remembering that hard power mechanisms of engagement between countries use carrots as inducements and sticks as threats so that a country achieves preferred outcomes out of the engagement, we will examine the hard power mechanisms in the NMSR which I will discuss shortly.

The NMSR is highly linked to the economic and financial support from Asian Investment Infrastructure Bank for effective implementation of the projects under the initiative. The initiative provides economic opportunities to ASEAN countries to access funds for the implementation of its infrastructures as outlined in the ASEAN vision of One Community One Destiny [26]. Although these funds will be necessary for financing implementation of infrastructure development projects in ASEAN, China could have a choice to use these economic and financial opportunities as carrots toASEAN for demanding some changes in policy, possibly in areas of politics and security. It may also decide to use a strategy of withholding the financial support as a precondition of influencing changes in ASEAN security policy matters. In these particular cases, it would increasingly be appropriate to describe the NMSR as Chinese hard power mechanism of achieving its national interests since this would conform to the theoretical logic of hard power as defined by scholars $[13,14,15]$ above. Indeed economic and financial resources that could be accrued by ASEAN countries out of this engagement might act as carrots for inducing compliance of ASEAN to assist China achieve its desired and preferred outcomes whether in economic, political or security arenas, thus confirming the logic of hard power mechanism of engagement.

Another hard power element in the NMSR could manifest itself in the development and construction of maritime or sea ports for the promotion and advancement of trade. Many scholars have argued that seaports which are to be constructed under this initiative might be controlled by China and in future be strategically used as military launch pads in the process of providing for its own security [27]. An example could be a seaport China is constructing in Djibouti where fears are high that such a port is being constructed as a strategic counterbalance to the military bases already constructed by both the U.S and France in this country. It is therefore the researcher's opinion that if not discussed and agreed upon properly, the fears that China could use these sorts of infrastructures as military bases could escalate, thereby raising fears that the initiative of NMSR is a strategy of developing China's hard power across the sea trade lanes when in actual fact, it has to be regarded as the development strategy of strengthening economic cooperation and regional integration.

The perception by the U.S and its allies in East Asia that the initiative is a Chinese strategy of dominating the geopolitical zone of South China Sea is another source of problem for China. The U.S sees the NMSR as a geopolitical strategy of China to control sea trade lanes, establish it'seconomic, political and security influence and extend its military range in the sea [28]. The focus of the U.S to establish and strengthen its military alliance and build up military arsenal in South China Sea is seen by China as offensive charm. Following the logic of defensive realism, China argues that it is reciprocating by building up its own military facilities on the islands of the sea as defensive and counter-balancing mechanisms. Related to this project of building up of military facilities on sea -islands by China, one can project that seaports that could be developed under the MSR could in future be used as hard power mechanisms of engagement, targeting not necessarily ASEAN countries but the U.S to counter-balance its military prowess in the region. Therefore this is another element of hard power mechanism isolated in the NMSR initiative.

\subsection{Soft Power elements in the $21^{\text {st }}$ Century Maritime Silk Road.}

Soft power has been defined as the ability to shape the preference of others in line with what you prefer to be your desired outcomes. Scholar [11] reasoned that countries are attracted to a particular country based on its values and identity which are inherently expressed in culture, ideologies and the foreign policies that a country is trying to project and pursue within its own country or in the way it handles itself internationally. The critical basis of this argument is that a country can attract other countries follow and emulate its development policies if those policies do not appear to have negative effects to other countries'core interests.

Ever since the $21^{\text {st }}$ Century MSR was conceptualized, it has so far received some positive remarks and ASEAN countries see it as a positive sign of Chinese peaceful development. In the opinion of some scholars, the NMSR is a strong sign that China wants to run away from the mentality that a strong country must become hegemon 
[29], but instead brings along the Chinese philosophy of togetherness and oneness [30]. The mere fact that most countries along the NMSR have expressed to support implementation of this initiative indicates strong signs of Chinese development of its soft power through this. It could therefore posited that the ASEAN countries are attracted to this initiative because this development policy appears to be good as it is oriented towards win-win cooperation.The initiative has also got the objective of strengthen social ties between the people of the region along the MSR as it will promote people-to-people exchange and visits amongst countries. Through these visits, I posit that there will be exchange of cultural values and development of new ideas on changing the perception on how the countries perceive each other. These are the clear signs of soft power elements within the Chinese engagement with ASEAN through the initiative.

\subsection{Where is the Strategic Smart Power in the $21^{\text {st }}$ Century Maritime Silk Road?}

I have argued and isolated the elements of hard and soft power in the engagement of China with ASEAN countries through the NMSR. I also showed and proved how China is striking a balance between deployment of both hard and soft power in its engagement with ASEAN. From hard power point of view, the researcher has argued that the economic and financial benefits coming out of MSR through AIIB are carrots for ASEAN countries to implement the initiative while the overall favourable picture of the development framework policy is a soft power for Chinese to attract ASEAN countries more into its strategic economic, political and security spheres of influence.From the foregoing argument, we can see both hard and soft powers being used by China in its engagement with ASEAN countries.However, the U.S has also got special interests in the Chinese engagement with ASEAN through this MSR initiative and I posit that the U.S would not just sit low and see events unfolding. It is likely to continue bringing along the elements of hard power in its support of ASEAN to strengthen its securitywithin the geopolitical zone of South China Sea where the NMSR will be implemented too. In fact, the U.S's continued military buildup in the South China Seaseemingly has necessitated China to start also building up its military arsenals on islands of the sea, thereby further exacerbating the security dilemma in the sea. I argue that the Chinese deployment of hard power mechanism in terms of military hardware is not necessarily targeted at ASEAN but the United States, while the soft power elements as discussed above are targeted at attracting the attention of ASEAN countries develop further ties with China with the hope that this could promote mutual understanding of each other's interests, promote economic interdependence and regional integration and promote peace and development in the South China Sea. As it can be seen, China is not necessarily relying on the deployment of one tool of engagement with ASEAN. It is using both soft power and hard power tactics. These tactics are what I have termed as strategic smart power with Chinese characteristics vis-à-vis china's deployment of soft power aimed at attracting ASEAN, economic and hard power use aimed at inducing ASEAN implement MSR and military hard power mechanisms focused on counter-balancing the U.S buildup of military arsenal in the South China Sea.

\section{IMPLICATIONS OF CHINA'S STRATEGIC SMART POWER ON} ASEAN AND THE U.S

The U.S has got geopolitical and geostrategic interests in the South China Sea as reflected in its AsiaPacific Pivot and Rebalancing Strategy [31]. China's deployment of strategic smart power could be interpreted as offensive charm for China to counter security strategic positioning of the U.S in the East Asia region. If not properly explained, this could escalate issues of security dilemma grounded in the theoretical logic of power balancing.ASEAN's interests in NMSR initiative is basically oriented towards its infrastructure which ideally is expected to be financed by AIIB [32]. If China decides to use this financial and economic power in a coercive manner to achieve its goals, the implementation of the initiative itself could be challenged. Trust building by China and ASEAN could be very important in strengthening collective efforts towards implementing the initiative. But considering the fact that China likely appears to be using strategic smart power as its foreign policy engagement mechanism with ASEAN in SCS, it increasingly becomes debatable whether there would be really full ASEAN support for the development initiative. While both ASEAN and China value the importance of promoting and enhancing economic interdependence and regional integration for common development and prosperity[33], the former might interpret the latter's exercise of strategic smart power as predatory initiatives aimed at suffocating its economic growth and development. In the likely event that could be the thinking on the part of ASEAN, one would posit that ASEAN cannot effectively support effective implementation of NMSR initiative on account of fearing the silent objectives of the initiative. It therefore incumbent upon China to display commitment towards mutual benefits and win-win situation through its exercise of economic and political power over ASEAN, if it were to get collaborative support on achievement of its core interests in NMSR. 


\section{RECOMMENDATIONS}

The Chinese use of strategic smart power through NMSR as a strategy of achieving its economic, political and security goals in South China Sea presents both benefits and challenges to ASEAN. Notwithstanding the positive benefits as outlined and examined herein, the element of hard power in the overall China's strategic smart power architecture could be problematic for ASEAN as they would interpret it as Chinese initiative to exercise its military and economic prowess in a negative way within the region. It therefore becomes paramount that China has to fully explain to its ASEAN strategic economic development partners what the real intention of the NMSR initiative is and how that is reflected in the deployment of China's soft power and smart power mechanisms. In the absence of such an explanation, it would be very difficult for China to get the trust of ASEAN for the effective implementation of the initiative. China needs to demonstrate both in strategy and its foreign policy that it is fully committed to establishing economic and political interdependence based on principles of win-win collaboration, equality, mutual benefit and common development and prosperity. The mere shift from use of hard power to strategic smart power will not be adequate enough for China to show ASEAN and the U.S that it is pursuing a path of peaceful development.

\section{CONCLUSION}

This paper has argued that China through the $21^{\text {st }}$ Century Maritime Silk Road has shifted from the initial deployment of hard power as sole mechanism of engagement with ASEAN in South China Sea. Instead it is now focusing on using a combination of both hard power and soft power mechanisms. This combination of these mechanisms is what I have called as strategic smart power with Chinese Characteristics.During the analysis and evaluation of the objective of this paper, the researcher managed to isolate and distinguish clear signs of hard power and soft power in the implementation of $21^{\text {st }}$ Century MSR by both China and ASEAN. It was argued that the soft power mechanism is targeted at attracting ASEAN countries support implementation of the initiative while the economic and financial hard power is targeted at inducing ASEAN support implementation of the project. The emerging military hard power is a counter-balance to the USA military alliance in South China Sea region but also to coerce ASEAN change its policies in compliance with the preferred outcomes by China.If China wants to fully get the trust of ASEAN in the effective implementation of the NMSR initiative, it has to demonstrate both in its foreign policy towards ASEAN and action that it has fully shifted from the sole use of hard power mechanisms to deployment of soft power when engaging with ASEAN countries. Otherwise, use of strategic smart power is as problematic as hard power mechanism is. Although the researcher thinks that soft power mechanism could be necessary tools of attracting ASEAN into China's economic and political orbits of influence, it increasingly appears that China prefers use of strategic smart power with Chinese characteristics.

Based on this, it could be concluded that through the NMSR, China is more likely to use strategic smart power as mechanism of engagement with ASEAN countries in South China Sea. The $21^{\text {st }}$ MSR could eventually be used as tool of reducing tensions over territorial disputes in the sea because the economic interdependence and integration developing out of MSR will place critical responsibilities on both China and ASEAN countries to promote peace and stability in the region.

\section{BIBLIOGRAPHY / REFERENCES}

[1] Attayanake, C (2016). China's MSR and ASEAN: Extension of Peaceful Development or Furthering Influence?

[2] Szczudlik-Tar, Justyna (2013). China's New Silk Road Diplomacy; Policy Paper vol.34 No. 84. The Polish Institute of International Affairs, December.

[3] Godement, F (2015). “ One Belt, One Road: China's Great Leap Outward”, European Council of Foreign Affairs, enfr.eu

[4] Attayanake, C (2016). China's MSR and ASEAN: Extension of Peaceful Development or Furthering Influence?

[5] Layne, C (2008). “ China's Challenge to US Hegemony; Current History.

[6] Mustonen, J.J (2010). Searching for China's use of soft power in pursuit of economic cooperation framework agreement with Taiwan

[7] Nye, J. Jr (2004). The soft power strategies of America

[8] Nye, J. Jr (2004). The soft power strategies of America

[9] Dahl, R (1961). The soft power mechanisms in Foreign Policy

[10] Trunkos, J (2013). What is soft power capability and how does it impact foreign policy?

[11] Nye, J Jr (2011). “The Future of Power.” Public Affairs, New York.

[12] Mustonen, J.J (2010). Searching for China's use of soft power in pursuit of economic cooperation framework agreement with Taiwan

[13] Nye, J. Jr (2004). The soft power strategies of America 
[14] Nye, J. Jr (2004). The soft power strategies of America

[15] Trunkos, J (2013). What is soft power capability and how does it impact foreign policy?

[16] Dahl, R (1961). The soft power mechanisms in Foreign Policy

[17] Dahl, R (1961). The soft power mechanisms in Foreign Policy

[18] Nye, J. Jr (2004). The soft power strategies of America

[19] Song, Y.H (2013). "The military and Securty Situation in the South Chn Sea", Institute of European and American Studies, Academia Sinica.

[20] Wu, J \& Zhang, Y (2013). "Xi in call for building of New Maritime Silk Road"; China Daily.

[21] Swaine, M.D (2014). Chinese Views and Commentary on Periphery Diplomacy, Retrieved from $\mathrm{http} / / \mathrm{www}$.hoover.org/research/Chinese view; China Leadership Monitor No.47

[22] Yifu, J (2014). Inserting Africa into One Belt One Road Strategy; A new Opportunity for job Creation and Infrastructure.

[23] Li, X and Worm, Vermer (2011). “ Building China's Soft Power for Peaceful Rise”; Journal of Chinese Political Science.

[24] Li, X and Worm, Vermer (2011). “ Building China's Soft Power for Peaceful Rise”; Journal of Chinese Political Science.

[25] Feitao, L (2013). “ Obama's Rebalancing to the Asia Pacific; China Institute of International Studies.

[26] Lau, L.J (2015). One Belt, One Road and Asian Infrastructure Investment Bank.

[27] Maitra, S (2016). The Perfect Security Dilemma in South China Sea; $18^{\text {th }}$ March, 2016.

[28] Lin, C (2011). "The New Silk Road China's Energy Strategy in the greater Middle East", The Washington Institute of Near East Policy.

[29] Beauchamp-Mustafaga, N (2015). Dispatch from Beijing: PLA Writings on the New Silk Road. China Brief.

[30] Attayanake, C (2016). "China's MSR and ASEAN: Extension of Peaceful Development or Furthering Influence?"; Central China Normal University, Political and International Studies Institute

[31] Mishara, R (2013). "The US Rebalancing Strategy / Pivot to Asia: Responses from South East Asia

[32] Lau, L.J (2015). One Belt, One Road and Asian Infrastructure Investment Bank.

[33] Salidjanova, N; Koch-Weser, I \& Klanderman, J (2015). " China's Economic Ties with ASEAN: A Country-by-Country Analysis.”; US-China Economic and Security Review 